\title{
Keahlian Penjualan, Perilaku Penjualan dan Kinerja Penjualan Salesforce PT Nasmoco Pemuda Semarang
}

\author{
Fitri Maulana ${ }^{1}$ \& Andi Wijayanto ${ }^{2, *}$ \\ ${ }^{1,2}$ Departemen Administrasi Bisnis, FISIP, Universitas Diponegoro, Indonesia \\ *Email: andibilt@gmail.com
}

\begin{abstract}
The purpose of the study is to determine the effect of sales skills and behavior on sales performance. The research population was 32 salesforces of PT. Nasmoco Pemuda Semarang. The primary data collected using questionnaires, interviews and observations. Data analysis using linear regression. The results indicate that sales skills has a positive and significant effect on the sales performance. The sales behavior has a positive and significant effect on the sales performance. Simultaneously, the sales skills and sales behavior positively have a significant effect on the sales performance. To improve sales performance, salespeople are expected to further increase their sales behavior because it is a more dominant variable. To increase sales behavior, salespeople are expected to be more responsive to listen to what prospective buyers say, not be proactive.
\end{abstract}

\begin{abstract}
Abstraksi: Tujuan penelitian ini adalah untuk mengetahui pengaruh variabel keahlian penjualan dan variabel perilaku penjualan pada kinerja penjualan. Sebagai populasi penelitian adalah sebanyak 32 tenaga penjual PT. Nasmoco Pemuda Semarang. Penelitian menggunakan data data primer yang dikumpulkan dengan menggunakan kuesioner, wawancara dan observasi. Analisis data menggunakan regresi linier. Penelitian menyimpulkan bahwa keahlian penjualan secara positif dan signifikan berpengaruh terhadap kinerja penjualan. Perilaku penjualan secara positif dan signifikan berpengaruh terhadap kinerja penjualan. Variabel keahlian penjualan dan perilaku penjualan secara serentak memiliki pengaruh signifikan terhadap kinerja penjualan. Sebaiknya dalam meningkatkan kinerja penjualan seharusnya tenaga penjual lebih meningkatkan lagi perilaku penjualannya karena merupakan variabel yang lebih dominan pengaruhnya. Untuk meningkatkan perilaku penjualan diharapkan tenaga penjual agar lebih responsif mendengarkan apa yang dikatakan calon pembeli, tidak bersikap proaktif.
\end{abstract}

Keywords: Sales Skills; Sales Behavior; Sales Performance

\section{Pendahuluan}

Salah satu sumberdaya penting bagi perusahaan untuk bertahan, tumbuh dan memajukan usahanya adalah sumberdaya manusia. Kinerja karyawan yang tinggi atau optimalnya hasil kerja yang dicapai oleh karyawan dalam melakukan tugas sesuai dengan tanggung jawab yang diberikan kepadanya akan mempengaruhi keberhasilan perusahaan. Karyawan merupakan sumberdaya utama bagi perusahaan karena keterampilan dan kreativitas karyawan sangat berguna bagi organisasi bisni dalam mencapai tujuannya. Johlke (2006), terkait dengan peran keahlian penjualan, dalam hasil penelitiannya menunjukkan bahwa keahlian penjualan salesman yang meliputi keaktifan dalam mendengarkan, kemampuan penjualan secara adaptif, tingkat pengetahuan tentang produk, proses penutupan penjualan, keahlian dalam bernegosiasi, dan prospecting memiliki pengaruh positif terhadap kinerja penjualan. Selanjutnya Pettijohn et al, (2007) menyimpulkan dalam penelitiannya bahwa keahlian dalam melakukan penjualan berpengaruh positif terhadap kinerja salesman dan secara negatif berpengaruh terhadap keinginan (intention) untuk berhenti. Selain itu keahlian penjualan juga berpengaruh terhadap orientasi terhadap pelanggan, tingkat kepuasan kerja, dan sikap komitmen terhadap organisasi.

Perilaku tenaga penjual menurut Pettijohn et al, (2007) adalah perilaku yang meliputi selalu bersikap sopan, mementingkan pelanggan, mau mendengarkan, membuat pelanggan merasa dihargai dan tidak merendahkan. Baldauf dan Cravens (2002) mendefinisikan perilaku tenaga penjualan sebagai penggunaan aspek 
pengetahuan teknis, aspek kemampuan penjualan secara adaptif dan perencanaan dalam penjualan. Weitz (dalam Brashear et al., 1997) mengungkapkan adanya hubungan secara langsung antara perilaku penjualan dengan efektivitas penjualan. Berdasarkan uraian di atas, dapat disimpulkan bahwa keahlian penjualan dan perilaku penjualan memiliki peran penting dalam meningkatkan kinerja penjualan.

Tabel 1. Market Share Toyota Tahun 2012-2017

\begin{tabular}{cccc}
\hline Tahun & $\begin{array}{c}\text { Produksi } \\
\text { Mobil } \\
\text { Nasional } \\
\text { (Unit) }\end{array}$ & $\begin{array}{c}\text { Produksi } \\
\text { Toyota } \\
\text { (Unit) }\end{array}$ & $\begin{array}{c}\text { Market } \\
\text { Share } \\
\text { (\%) }\end{array}$ \\
\hline 2012 & 837.869 & 319.647 & 38,15 \\
\hline 2013 & 1.052 .855 & 445.463 & 42,31 \\
\hline 2014 & 1.206 .334 & 489.289 & 40,56 \\
\hline 2015 & 1.300 .237 & 542.719 & 41,74 \\
\hline 2016 & 1.227 .258 & 526.371 & 42,89 \\
\hline 2017 & 1.177 .767 & 537.415 & 45,63 \\
\hline
\end{tabular}

Sumber: Gaikindo (2018)

Dari tabel 1 diketahui bahwa market share Toyota pada tahun 2012-2017 mengalami kecenderungan naik/bertambah. Hal ini dapat dilihat bahwa dalam 3 tahun terakhir market share produk Toyota mengalami kenaikan. Penurunan hanya terjadi pada tahun 2014, tetapi total produksi unit toyota jika dibandingkan dengan tahun sebelumnya mengalami kenaikan. Hal tersebut menunjukkan bahwa produk Toyota memiliki market share yang bagus dan cenderung naik di tiap tahunnya, tetapi data penjualan yang peneliti dapatkan dari hasil perolehan di PT. Nasmoco Pemuda Semarang cenderung mengalami penurunan dan pencapaian target dari tenaga penjualan yang cenderung menurun atau tidak memenuhi target yang ditetapkan. Kondisi tersebut secara detil ditunjukkan pada Tabel 2.

Dari tabel 2 dapat diketahui bahwa terjadi fluktuasi pada jumlah persentase realisasi dari target yang cenderung mengalami penurunan pada periode 20122017.
Tabel 2. Data Penjualan PT. Nasmoco Pemuda Semarang Tahun 20122017

\begin{tabular}{cccc}
\hline Tahun & Target & Realisasi & Persentase \\
\hline 2012 & 700 & 740 & 105,7 \\
\hline 2013 & 950 & 935 & 98,4 \\
\hline 2014 & 1200 & 1031 & 85,9 \\
\hline 2015 & 1600 & 1542 & 96,3 \\
\hline 2016 & 1900 & 1678 & 88,3 \\
\hline 2017 & 2200 & 1850 & 84,3 \\
\hline
\end{tabular}

Sumber: PT. Nasmoco Pemuda Semarang (2018)

Berdasarkan masalah tersebut, maka penelitian ini bermaksud meneliti pengaruh keahlian dan perilaku penjualan terhadap kinerja tenaga penjual. Pertanyaan penelitian ini dapat dirumuskan sebagai berikut: (1) Apakah keahlian penjualan berpengaruh signifikan terhadap kinerja penjualan?; (2) Apakah perilaku penjualan berpengaruh signifikan terhadap kinerja penjualan?; (3) Apakah keahlian penjualan tenaga penjual dan perilaku penjualan tenaga penjual secara bersama-sama berpengaruh signifikan terhadap kinerja penjualan tenaga penjual?

\section{Kajian Teori}

Manajemen sumberdaya manusia (MSDM) merupakan ilmu dan seni yang mengendalikan hubungan serta peranan tenaga kerja agar menjadi efektif serta efisien dalam mendukung tercapainya tujuan perusahaan, tujuan karyawan dan tujuan masyarakat (Bintoro \& Daryanto, 2017). Ruang lingkup manajemen sumberdaya manusia melibatkan hal-hal sebagai berikut, yaitu human resource planning, perencanaan dan persiapan sumberdaya manusia yang akan dibutuhkan oleh organisasi atau perusahaan; job analysis atau analisis jabatan, yaitu penjabaran secara detil setiap pekerjaan dan atau jabatan di dalam perusahaan atau organisasi; recruitment and selection, merekrut dan menyeleksi karyawan yang dibutuhkan sesuai dengan persyaratan, prosedur, sistem, dan proses yang telah ditentukan untuk dapat memenuhi kebutuhan perusahaan dan atau organisasi baik di saat ini maupun di masa depan; orientation an induction, yaitu masa dimana organisasi atau perusahaan mengenalkan kepada karyawan 
mengenai latar belakang, budaya dan nilainilai organisasi atau perusahaan serta etika kerja; training and development, meliputi pelatihan serta pengembangan sumberdaya manusia dalam perusahaan/organisasi; performance appraisal, yaitu penilaian prestasi atau kinerja karyawan sebagai dasar dalam melakukan transfer, promosi dan demosi, serta pemberhentian hubungan kerja (PHK) terhadap karyawan; compensation planning and remuneration, perencanaan pengupahan dan kompensasi; motivation, welfare, healthy, and safety, meliputi kegiatan untuk memotivasi para karyawan, memberi perhatian pada kesejahteraan, kesehatan serta keselamatan karyawan; industrial relations, yaitu dengan menjaga komunikasi dan hubungan yang harmonis dan baik dengan serikat pekerja.

Berdasarkan ruang lingkup MSDM, fokus riset ini adalah pada poin upaya untuk meningkatkan ketrampilan dan perilaku karyawan melalui pelatihan dan pengembangan sumberdaya manusia (Training and Development) di dalam organisasi salah satunya adalah pelatihan pada tenaga penjual. Dengan dilakukannya pelatihan terhadap tenaga penjual akan berdampak pada peningkatan keahlian penjualannya, baik peningkatan keahlian penjualan (teknik penjualan) maupun perilaku penjualan.

\section{Keahlian Penjualan}

Keahlian menjual (selling skill) merupakan pengetahuan khusus yang dimiliki oleh tenaga penjualan yang mendukung dalam menjalankan hubungan bisnis (Liu \& Leach, 2001). Pettijohn et al., (2007) mendefinisikan keahlian penjualan sebagai ketrampilan yang dimiliki oleh seorang tenaga penjual yang berkontribusi pada kegiatan penjualan yang dilakukannya. Faktor keahlian penjualan mencakup aspek penjualan yang mencerminkan keterampilan dan keterampilan khusus yang sesuai dengan pelatihan dan pengembangan. Hal tersebut meliputi teknik pendekatan, pencarian prospek, penanganan keberatan, negosiasi, mendorong pembelian, pengetahuan produk, membuat konsumen berbicara, mempelajari, presentasi dan penutupan. Aspek-aspek dalam ketrampilan presentasi penjualan antara lain meliputi keaktifan dalam mendengar, penjualan adaptif, penanganan akan keberatan, penutupan, kemampuan bernegosiasi dan pencarian (Johlke, 2006). Dalam MarkPlus MIM Academy (2010) ketrampilan menjual terdiri dan prospecting, approaching, menjajaki pelanggan, mengkonsultasikan solusi, teknik menawarkan produk, menangani penolakan, penutupan penjualan, dan layanan purnajual. Keahlian penjualan juga dideskripsikan sebagai orientasi dari seseorang tenaga penjual untuk selalu berusaha melakukan perbaikan dan meningkatkan kemampuannya serta penguasaan atas tugas dan tanggungjawab pekerjaannya (Sujan et al., 1994).

\section{Perilaku Penjualan}

Perilaku penjualan oleh Pettijohn et al., (2007) didefinisikan sebagai perilaku seorang tenaga penjual yang meliputi selalu bersikap sopan, mementingkan pelanggan, kemauan mendengarkan, kemampuan membuat pelanggan selalu merasa dihargai dan tidak merendahkan. Perilaku tenaga penjual yang positip sangat diperlukan dalam mendukung keberhasilan proses penjualan yang akan dan sedang dilakukannya serta aktivitas yang berhubungan pada pengembangan hubungan dengan pelanggan. Proses yang terjadi dalam perilaku penjualan antara lain meliputi proses pemrospekan, proses pencarian fakta, proses terjadinya penjualan, proses pelayanan terhadap pelanggan dan proses penutupan penjualan. Penelitian lainnya yang meneliti mengenai keterkaitan antara perilaku penjualan dengan kinerja adalah penelitian yang dilakukan oleh Weitz (dalam Brashear et al, 1997). Hasil penelitiannya menyatakan bahwa perilaku penjualan tenaga penjual berhubungan langsung dengan efektivitas penjualan tenaga penjual. Persepsi peran dan motivasi dapat berperan sebagai mediator pada hubungan tersebut (Brown dan Peterson, 1994). Upaya tersebut menunjukkan adanya dampak positif terhadap tingkat kinerja dari seorang tenaga penjual. 


\section{Kinerja Penjualan}

Kinerja penjualan didefinisikan oleh Churchill et al. (1993) sebagai evaluasi terhadap perilaku seorang tenaga penjual yang memberikan kontribusi atau sumbangan pada keberhasilan secara objektif. Pettijohn et al., (2007) mendefinisikan kinerja penjualan sebagai pengukuran yang berfokus pada keberhasilan objektif yang terdiri dari lima item yang terdiri dari kontribusi tenaga penjual pada pangsa pasar, menaikkan tingkat profitabilitas perusahaan, kecepatan dalam menjual produk baru, kemampuan dalam memenuhi target perusahaan, serta membantu supervisor memenuhi tujuannya. Kinerja tenaga penjual didefinisikan oleh Baldauf (2001) sebagai "suatu bentuk evaluasi dari kontribusi-kontribusi tenaga penjual untuk mencapai tujuan tujuan organisasi”.

Penilaian terhadap kinerja organisasi secara keseluruhan menempatkan kinerja tenaga penjual sebagai salah satu aspek penting. Penyebabnya tidak lain adalah pentingnya peran tenaga penjual sebagai bagian dari organisasi secara keseluruhan untuk menjual produk-produk yang dihasilkan oleh perusahaan. Menurut Sujan et al. (1994) kinerja tenaga penjualan dibentuk oleh kemampuannya dalam menghasilkan pendapatan yang tinggi bagi perusahaan. Royan (2004) menjelaskan bahwa kinerja tenaga penjual dievaluasi melalui indikator prestasi kerja dan sikap. Evaluasi kinerja tenaga penjual melibatkan sikap karena tanpa sikap yang baik, berarti tenaga penjual bukanlah pekerja yang memiliki etos kerja baik. Selain itu, tenaga penjual memang berbeda dengan karakteristik pekerja di bidang lainnya, misalnya administrasi atau yang lain. Seoarang sales force yang pandai menjual tetapi tidak dapat mendongkrak kinerja penjualan perusahaan, maka ia tidak lebih dari Sinterklas belaka.

Singkatnya, seorang penjual tidak hanya dituntuk untuk memiliki ketrampilan yang baik dalam melakukan penjualan, tetapi juga bertanggung jawab dalam meningkatkan kinerja penjualan perusahaan.

\section{Pengembangan Hipotesis}

Beberapa penelitian terdahulu menggunakan perspektif pembeli dalam mengukur keahlian penjual. Keterkaitan antara variabel persepsi pembeli dari taktik alternatif penjualan dengan efektifitas penerimaan mereka pernah diteliti oleh DelVecchio et al., (dalam Pettijohn et al., 2007). Indikasi dari hal tersebut adalah bahwa pembeli ternyata memberi respon terhadap perbedaan taktik-taktik penjualan yang dilakukan dengan basis pada variabilitas karakteristik pembeli. Seorang tenaga penjual yang memiliki kinerja yang baik tergantung pada keahlian serta perilaku penjualan yang akan berdampak pada tinggi rendahnya kinerja penjualan yang dicapainya (Piercy et al, 1998). Johlke (2006) berdasarkan hasil penelitiannya menyimpulkan bahwa keahlian penjualan tenaga penjual yang meliputi keaktifan mendengarkan, kemampuan menjual secara adaptif, tingkat pengetahuan terhadap produk, proses penutupan, kemampuan bernegosiasi, dan proses pemrospekan berpengaruh positif pada kinerja penjualannya.

Dengan demikian, dari penjelasan teoritis dan empiris bahwa seorang tenaga penjual yang memiliki keahlian yang tinggi akan berpengaruh lebih tinggi pula terhadap kinerja penjualannya mengarahkan pada penyusunan hipotesis pertama dalam penelitian ini, yaitu:

\section{$\mathrm{H}_{1}$ : keahlian penjualan berpengaruh} signifikan terhadap kinerja penjualan.

Perilaku penjualan seorang tenaga penjual akan memiliki dampak yang berbeda pada kinerja tenaga penjualannya (Brashear et al, 1997). Khususnya pada kegiatan yang terkait langsung dengan penjualan dan servis klien akan memiliki pengaruh yang lebih besar pada kinerja seorang tenaga penjual daripada hal-hal yang berkaitan dengan dukungan penjualan dan pengembangan pribadi. Dengan demikian, hipotesis kedua pada penelitian ini adalah: 


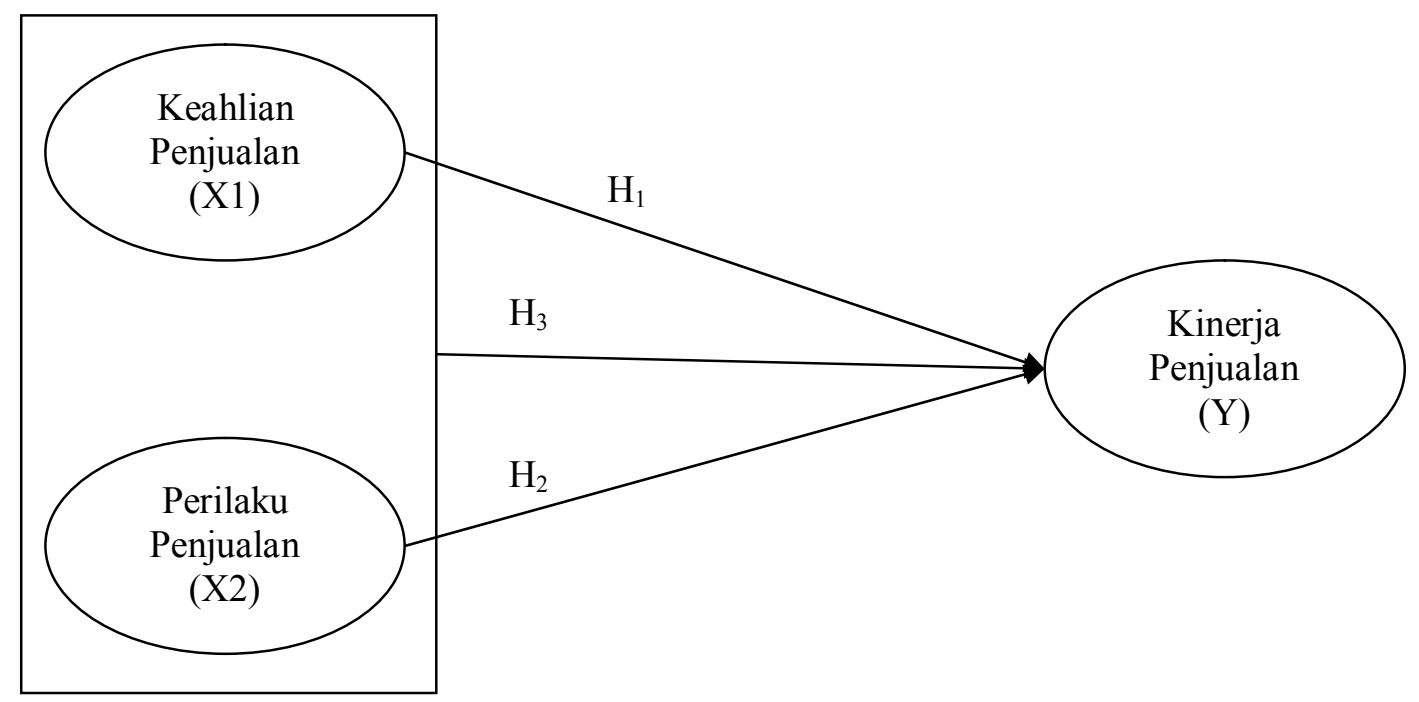

\section{Gambar 1. Model Hipotesis}

$\mathrm{H}_{2}$ : perilaku penjualan berpengaruh signifikan terhadap kinerja penjualan.

Peningkatan keahlian penjualan yang menurut Pettijohn et al. (2007) menjelaskan bahwa keahlian penjualan terbagi menjadi 2 yaitu keahlian penjualan yang merupakan teknik penjualan dan perilaku penjualan. Morris et al, (dalam Morgan, 1996) dalam penelitiannya menemukan bahwa ketika senior manajer penjualan menyatakan untuk menilai pentingnya berbagai macam perilaku dan hasilnya yang berbasis pada faktor kinerja, peringkat mereka pada hampir semua faktor perilaku yang berbasis konvensional adalah lebih tinggi dibandingkan hasil berbasis faktor seperti penjualan, laba bersih, dan akun baru. Dapat ditarik kesimpulan bahwa keahlian penjualan dan perilaku penjualan secara bersama-sama memiliki pengaruh terhadap kinerja penjualan. Penjelasan ini mengarah kepada pernyataan hipotesis ke tiga, yaitu:

$\mathrm{H}_{3}$ : keahlian penjualan dan perilaku penjualan secara bersama-sama berpengaruh signifikan terhadap kinerja penjualan.

Model hipotesis dari ketiga pernyataan hipotesis penelitian selengkapnya ditunjukkan pada Gambar 1.

\section{Metode}

Penelitian ini menggunakan tipe penelitian penjelasan atau yang lebih dikenal dengan explanatory research. Sampel penelitian adalah seluruh tenaga penjual di PT. Nasmoco Pemuda Semarang yang berjumlah 32 orang. Pengambilan sampel dilakukan dengan teknik sensus dimana semua anggota populasi dijadikan sampel. Penelitian menggunakan data data primer yang dikumpulkan dengan menggunakan kuesioner, wawancara dan observasi. Teknik analisis data yang digunakan pada penelitian ini adalah analisis regresi linear.

\section{Hasil dan Pembahasan}

Berdasarkan pada hasil penelitian yang dilakukan, maka dapat dideskripsikan karakteristik responden sebagaimana ditunjukkan pada Tabel 3.

Berdasarkan pada tabel 3 dapat diketahui bahwa sebagian jenis kelamin besar karyawan bagian salesforce adalah laki-laki. Alasan karyawan didominasi oleh laki-laki adalah karena pria cenderung tergolong lebih mobile dibandingkan wanita dalam hal kegiatan penjualan. Hal ini juga dipengaruhi oleh para salesman pria yang diharuskan 
untuk terjun langsung mencari calon pembeli, sehingga diperlukan performa fisik yang lebih tangguh.

Tabel 3. Karakteristik Responden

\begin{tabular}{|c|c|c|}
\hline No. & Karakteristik & $\begin{array}{c}\text { Persentase } \\
(\%)\end{array}$ \\
\hline \multirow{3}{*}{1.} & Jenis Kelamin & \\
\hline & Perempuan & 18,75 \\
\hline & Laki-Laki & 81,25 \\
\hline \multirow{7}{*}{2.} & Usia & \\
\hline & $24-25$ & 50,00 \\
\hline & $26-27$ & 31,26 \\
\hline & $28-29$ & 3,12 \\
\hline & $30-31$ & 6,25 \\
\hline & $32-33$ & 3,12 \\
\hline & $34-35$ & 6,25 \\
\hline \multirow{4}{*}{3.} & Tingkat Pendidikan & \\
\hline & Tamat SMA & 18,75 \\
\hline & Akademi/Diploma & 28,13 \\
\hline & Sarjana & 53,12 \\
\hline \multirow{5}{*}{4.} & Masa Kerja & \\
\hline & $<3$ tahun & 31,25 \\
\hline & 3 tahun - 4 tahun & 21,88 \\
\hline & 5 tahun -6 tahun & 9,37 \\
\hline & $>6$ tahun & 37,50 \\
\hline \multirow{5}{*}{5.} & Rata-Rata Penghasilan & \\
\hline & Bulanan & \\
\hline & $2.500 .000-5.000 .000$ & $\begin{array}{l}46,81 \\
37,50\end{array}$ \\
\hline & $>5.000 .000-7.500 .000$ & 15,63 \\
\hline & $>7.500 .000$ & \\
\hline
\end{tabular}

Sumber: Data primer, diolah (2019)

Usia responden sebagian besar berusia relatif masih muda dengan kisaran umur yang tergolong sangat produktif. Untuk tingkat pendidikan mayoritas responden telah mengenyam pendidikan formal yang tinggi karena data menunjukkan mayoritas responden adalah sarjana. Lama bekerja menjadi salah satu hal yang berpengaruh, dimana semakin lama bekerja maka pengalaman dan keahlian dalam menjual akan semakin baik. Dapat diketahui karyawan yang menjadi responden penelitian ini memiliki masa kerja yang bervariatif, tetapi untuk masa kerja lebih dari 6 tahun lebih dominan jumlahnya sehingga hasil ini menunjukkan bahwa karyawan telah berpengalaman dan senior di bidang penjualan. Terakhir adalah rata-rata penghasilan responden yang menunjukkan bahwa seluruh responden berpenghasilan cukup tinggi dan diatas UMR (Upah Minimum Regional) kota Semarang.

Berdasarkan analisis data penelitian yang dilakukan, maka dapat disajikan informasi sebagaimana ditunjukkan pada Tabel 4.

Hasil uji analisis regresi linier sederhana menunjukkan bahwa variabel keahlian penjualan dengan kinerja penjualan memiliki nilai signifikansi 0,001 . Nilai tersebut adalah lebih kecil dibandingkan dengan tingkat signifikansi yang digunakan yaitu $0,001<$ 0,05 , serta nilai t hitung 3,513 lebih besar dibandingkan nilai $t$ tabel 2,042. Sehingga dapat ditarik kesimpulan bahwa keahlian penjualan berpengaruh positip dan signifikan terhadap kinerja penjualan. Hasil ini memberi indikasi bahwa apabila keahlian penjualan semakin kuat, maka akan meningkatkan kinerja penjualannya. Begitu pula sebaliknya bila keahlian penjualan lemah maka kinerja penjualan juga akan menurun.

Peningkatan keahlian penjualan dapat dilakukan dengan pengembangan melalui pelatihan. Terdapat 6 indikator yang memiliki skor dibawah skor rerata yaitu pertanyaan yang menarik minat calon pembeli, pernyataan yang menarik minat calon pembeli, mengatasi keberatan/penolakan calon pembeli mempelajari, negosiasi dan penutupan. Indikator-indikator inilah yang perlu ditingkatkan lagi oleh perusahaan untuk meningkatkan keahlian penjualan tenaga penjualnya. Terdapat beberapa macam pelatihan yang diselenggarakan PT. Nasmoco Group, di antaranya adalah pelatihan bagi salesman baru dan salesman yang sudah lebih senior. Terdapat FST (First Sales Training) untuk salesman baru, yang diadakan setiap 23 bulan setelah menjadi salesman baru. Kemudian PSST (Professional Selling Skill Training) untuk salesman junior sampai dengan senior. Waktu pelaksanaan pelatihanpelatihan di atas adalah selama satu minggu penuh yang diadakan di pusat pelatihan (Nasmoco Training Centre) dan 
diperuntukkan bagi semua salesman PT.

yang memiliki nilai dibawah skor rerata yaitu mendengarkan dan membuat pelanggan

Tabel 4. Hasil Analisis Data

\begin{tabular}{lllllll}
\hline \multirow{2}{*}{ No. Hipotesis } & \multicolumn{5}{c}{ Hasil } & \multirow{2}{*}{ Ket. } \\
\cline { 2 - 5 } & Korelasi & $\begin{array}{c}\text { Koefisien } \\
\text { Determinasi }\end{array}$ & $\begin{array}{c}\mathrm{t} \\
\text { hitung }\end{array}$ & $\begin{array}{c}\mathrm{F} \\
\text { hitung }\end{array}$ & Sig & \\
\hline & & & & & & \\
\hline $\begin{array}{l}\text { Keahlian penjualan } \\
\text { berpengaruh signifikan } \\
\text { terhadap kinerja } \\
\text { penjualan }\end{array}$ & 0,540 & 0,291 & 3,513 & - & 0,001 & $\begin{array}{c}\text { Hipotesis } \\
\text { diterima }\end{array}$ \\
\hline $\begin{array}{l}\text { Perilaku penjualan } \\
\text { berpengaruh signifikan } \\
\text { terhadap kinerja } \\
\text { penjualan }\end{array}$ & 0,400 & 0,160 & 2,393 & - & 0,023 & $\begin{array}{c}\text { Hipotesis } \\
\text { diterima }\end{array}$ \\
\hline $\begin{array}{l}\text { Keahlian penjualan dan } \\
\text { perilaku penjualan } \\
\text { secara bersama-sama } \\
\text { berpengaruh signifikan } \\
\text { terhadap kinerja } \\
\text { penjualan }\end{array}$ & 0,534 & 0,285 & & 5,792 & 0,008 & $\begin{array}{c}\text { Hipotesis } \\
\text { diterima }\end{array}$ \\
\hline
\end{tabular}

Sumber: Data primer yang diolah, 2019

\section{Nasmoco Group.}

Hasil uji analisis regresi linier sederhana menunjukkan bahwa variabel perilaku penjualan dengan kinerja penjualan memiliki tingkat signifikansi 0,023 . Nilai tersebut lebih kecil dibandingkan dengan tingkat signifikansi yang digunakan yaitu 0,05 . Nilai t hitung sebesar 2,393 adalah lebih besar daripada nilai t tabel 2,042. Sehingga dapat ditarik kesimpulan bahwa perilaku penjualan berpengaruh positip dan signifikan terhadap kinerja penjualan.

Hasil ini memberi indikasi bahwa apabila perilaku penjualan semakin baik, maka akan meningkatkan kinerja penjualannya. Begitu pula sebaliknya bila perilaku penjualan buruk maka kinerja penjualan juga akan menurun. Dalam pendidikan perilaku penjualan di PT Nasmoco Pemuda Semarang termasuk dalam kurikulum pelatihan yang diberikan oleh perusahaan. Dalam melakukan pengembangan sumberdaya manusia, khususnya tenaga penjual perusahaan memberikan pendidikan pendapat dan moral bagi para karyawannya. Terdapat 2 indikator selalu dihargai. Indikator-indikator inilah yang perlu ditingkatkan agar perilaku penjualan semakin baik. Diharapkan dengan hal tersebut mampu untuk meningkatkan perilaku tenaga penjual ke arah yang semakin baik. Karena sangat penting sebuah pendapat atau perilaku yang baik oleh tenaga penjual saat mereka harus berhadapan dan melayani pelanggan baik secara langsung maupun tidak langsung. Dengan semakin baiknya perilaku penjualan maka akan semakin baik pula kinerja penjualannya.

Analisis regresi linier berganda yang telah dilakukan menghasilkan nilai $\mathrm{F}$ hitung sebesar 5,792 yang lebih besar dibandingkan $\mathrm{F}$ tabel yaitu 3,32. Berdasarkan hal tersebut, maka dapat ditarik kesimpulan bahwa variabel keahlian penjualan dan perilaku penjualan berpengaruh positif dan signifikan terhadap kinerja penjualan. Analisis dari hasil penelitian ini menunjukkan bahwa variabel perilaku penjualan memiliki pengaruh yang lebih kuat terhadap kinerja penjualan dengan nilai beta sebesar 0,371 . Tanda positif pada nilai Beta (P) menandakan bahwa semakin meningkat nilai dari variabel perilaku 
penjualan maka nilai kinerja penjualan juga akan meningkat. Sebab, perilaku dari seorang tenaga penjual yang secara langsung berinteraksi dengan calon pelanggan yang akhirnya dapat memaksimalkan nilai kinerja penjualannya. Hasil penelitian ini mengindikasikan bahwa perilaku penjualan lebih dominan pengaruhnya daripada keahlian penjualan. Manajemen PT. Nasmoco Pemuda Semarang disarankan untuk meningkatkan perilaku penjualannya dari indikator sikap mendengarkan calon pembeli agar lebih responsif dalam menanggapi apa yang dibicarakan calon pembeli. Melihat persaingan dan cepatnya perkembangan industri mobil, ujung tombak dari perusahaan adalah para tenaga penjualnya yang merupakan salah satu unsur penting bagi perusahaan. Memiliki tenaga penjual yang berkualitas akan meningkatkan kinerja perusahaan.

\section{Kesimpulan dan Saran}

\section{Kesimpulan}

Berdasarkan pada hasil penelitian, maka dapat ditarik beberapa kesimpulan. Pertama, variabel keahlian penjualan (Xi) berpengaruh positif serta signifikan terhadap variabel kinerja penjualan (Y). Keahlian penjualan tenaga penjual secara statistik berpengaruh positif serta signifikan pada kinerja tenaga penjual. Semakin tinggi keahlian penjualan yang dimiliki seorang tenaga penjual akan berpengaruh pada meningkatnya kinerja tenaga penjual. Kesimpulan penelitian ini mendukung temuan penelitian Pettijohn et al., (2007), yang menyimpulkan bahwa keahlian penjualan berpengaruh signifikan terhadap kinerja tenaga penjual. Jadi keahlian penjualan seperti pencarian prospek, pendekatan, pengetahuan produk, presentasi, membuat konsumen bicara, mendorong pembelian, penanganan keberatan, mempelajari, negosiasi dan penutupan berpengaruh positif dan signifikan pada kinerja penjualan mereka.

Kedua, variabel perilaku penjualan (X2) berpengaruh positif dan signifikan terhadap variabel kinerja penjualan (Y). Perilaku penjualan tenaga penjual dalam penelitian ini secara statistik berpengaruh positif dan signifikan terhadap kinerja penjualan tenaga penjual. Peningkatan perilaku penjualan seorang tenaga penjual akan berpengaruh pada meningkatnya kinerja penjualan. Hasil penelitian ini tidak mendukung kesimpulan penelitian Pettijohn et al., (2007) yang menemukan bahwa perilaku penjualan tidak berpengaruh signifikan pada kinerja penjualan tenaga penjual. Jadi, keahlian penjualan dan perilaku penjualan yang dimiliki oleh seorang tenaga penjual, seperti selalu bersikap sopan, mementingkan pelanggan, mendengarkan, membuat pelanggan selalu dihargai, dan tidak merendahkan dalam penelitian ini secara positif berpengaruh signifikan pada kinerja penjualan mereka.

Ketiga, secara serentak, variabel keahlian penjualan (X1) dan perilaku penjualan (X2) memiliki pengaruh signifikan terhadap variabel kinerja penjualan (Y). Semakin baik penilaian karyawan terhadap keahlian penjualan dan perilaku penjualan maka akan meningkatkan pula kinerja penjualan. Dalam penelitian terhadap karyawan PT. Nasmoco Pemuda Semarang ini, variabel keahlian penjualan dan perilaku penjualan secara simultan berpengaruh signifikan terhadap kinerja penjualan.

Keempat, variabel perilaku penjualan mempunyai pengaruh terbesar terhadap kinerja penjualan dengan nilai koefisien beta yang lebih besar daripada variabel keahlian penjualan.

Saran

Saran-saran yang dapat peneliti berikan diantaranya adalah: (1) Sebaiknya dalam meningkatkan kinerja penjualan seharusnya tenaga penjual lebih meningkatkan lagi perilaku penjualannya karena merupakan variabel yang lebih dominan pengaruhnya; (2) Bagi peneliti selanjutnya, disarankan agar menambahkan lingkup objek yang lebih luas; (3) Kontribusi variabel keahlian penjualan dan perilaku penjualan dalam menjelaskan variasi nilai variabel kinerja penjualan tenaga penjual PT Nasmoco Pemuda Semarang adalah sebesar $28,5 \%$. Sebesar $71,5 \%$ variasi nilai variabel kinerja penjualan dipengaruhi oleh faktor-faktor lain, sehingga saran bagi peneliti selanjutnya adalah dapat 
memasukkan beberapa variabel lainnya yang diprediksi berkontribusi pada kinerja penjualan salesman, seperti kepemimpinan, loyalitas, motivasi kepuasan kerja dan sebagainya.

\section{Daftar Referensi}

Baldauf, A. Cravens, D.V. (2002), "The effect of moderators on the salesperson behavior performance and salesperson outcome performance and sales organization effectiveness relationships". Europan Journal of Marketing, Vol. 36, pp. 1367-1388.

Bintoro \& Daryanto. 2017. Manajemen Penilaian Kinerja Karyawan. Yogyakarta: Gava Media.

Brashear, T.G, Bellenger, D.N, Ingram Tom and Barksdale, H.C. (1997), "Salesperson behavior: antecedents and links to performance". Journal of Bussines and Industrial Marketing, Vol. 12, pp. 177-184.

Brown, S.P. and Peterson, R.A. (1994), "The effect of effort on sales performance and job satisfaction," Journal of Marketing, Vol. 58, April, pp. 70-80.

Churchill, G.A. Jr, Ford, N.M., Hartley, S.W., Walker, O.C. Jr (1993), "The determinants of salesperson performance: a meta-analysis", Journal of Marketing Research, Vol. 22, pp.10318.

Ghozali, Imam. 2005. Aplikasi Analisis Multivariate dengan program SPSS, Semarang: Badan Penerbit Universitas Diponegoro.

Hendriyanto, Asepta. 2012. Analisis Pengaruh Keahlian Menjual Tenaga Penjual, Dan Kualitas Pelayanan Glaxo Smith Kleine Terhadap Kinerja Tenaga Penjual. Semarang: Sekolah Tinggi Ilmu Ekonomi Totalwin.

Johlke, Mark C. (2006) "Sales presentation skills and salesperson job performance",
Journal of Business \& Industrial Marketing, Vol. 21 Iss: 5, pp.311-319

Liu, A. H. \& Leach. (2001), "Developing Loyal Customers with a Value-Adding Sales Force: Examining Customer Satisfaction and the Perceived Credibility of Consultative Salespeople". Journal of Personal Selling \& Sales Management, XXI-(2).

Morgan, N.A. (1996), "Salesforce performance and behaviour-based management processes in businesstobusiness sales organizations". European Journal of Marketing, Vol. 32 , pp. 79-100.

Pettijohn, C.E, Pettijohn, L.S, and Taylor, AJ. (2007), "Does salesperson perception of the importance of sales skills improve sales performance, customer orientation, job satisfaction, and organizational commitment, and reduce turnover". Journal of Personal Selling and Sales Management, Vol. 27, pp. $75-88$.

Piercy, N.F, Cravens, D. V, Morgan, N. A. (1998), "Sales performance and behavior-based management processes in business-to-business sales organizations". Europan Journal of Marketing, Vol. 32, pp. 79 - 100.

Royan, Frans M. 2004. Creating Effective Sales Force, Meningkatkan Penjualan dengan Rancang Bangun Sales Force Effective. Yogyakarta: Andi.

Sujan, H., Weitz, B. A., \& Kumar, N. (1994). Learning orientation, working smart, and effective selling. Journal of marketing, 58(3), 39-52.

Syaifudin, Mochammad, Musriha, Bramastyo Kusumo Negoro. 2017. Analisis Pengaruh Bakat Penjualan, Persepsi Per an, Tingkat Keahlian Dan Kepribadian Terhadap Kinerja Tenaga Penjualan Azarine Kosmetik Spa Di Toko Mahkota Indah Sidoarjo. Surabaya: Universitas Bhayangkara. 
TIM Markplus. 2010. The

Sales Operation. Jakarta: ESENSI OfficialMIMAcademy

Coursebook:

Erlangga. 